EESTI NSV TEADUSTE AKADEEMIA TOIMETISED. 21. KÖIDE

KEEMIA * GEOLOOGIA. 1972, NR. 4

ИЗВЕСТИЯ АКАДЕМИИ НАУК ЭСТОНСКОИ ССР. ТОМ 21

ХИМИЯ * ГЕОЛОГИЯ. 1972, № 4

удК $551.733 .3(474.2)$

P. ЭИНАСТО, Х. НЕСТОР, Э. КАЛА, К. КАЯК

\title{
СОПОСТАВЛЕНИЕ ВЕРХНЕЛЛАНДОВЕРИЙСКИХ РАЗРЕЗОВ В ЗАПАДНОЙ ЭСТОНИИ
}

Региональный эквивалент верхнего лландовери в Эстонии - адавереский горизонт - представлен двумя литологически и палеонтологически четко различающимися толщами: известняками и вторичными доломитами с Pentamerus oblongus (=адавереская свита, по Кальо, 1970) и мергелями и глинами с фауной сообщества Clorinda, фациально переходящими в граптолитовые аргиллиты (=велизеская пачка, или свита, по Юргенсон, 1966; Кальо, 1970).

Согласно представлениям А. Аалоэ (1960), Э. Юргенсон (1966) и Д. Кальо $(1962 ; 1970)$, известняки с Pentamerus oblongus на востоке и велизеские мергели на западе одновозрастны и фациально замещают друг друга на территории Западной Эстонии между Матсалуским и Пярнуским заливами (рис. 1; см. также Аалоэ, 1960, рис. 2; Кальо, 1970, рис. 63 и 83).

Проведенные Р. Мяннилем (1970) исследования планктонных микрофоссилий в карбонатной и глинистой частях адавереского горизонта заставляют, однако, сомневаться в их одновозрастности. Им было установлено, что в низах пентамеровых слоев распространяется Verychuchium (=Estiastra), а в велизеских мергелях - Angochitina longicolla, т. е. виды, образующие разные возрастные зоны. На юго-западе Сааремаа (скв. Oхесааре) слои с Angochitina longicolla залегают непосредственно над отложениями райккюлаского горизонта, что может быть объяснено седиментационным перерывом, соответствующим отложению всей карбонатной части адавереского горизонта.

В то же время одними из нас (К. Каяком и Э. Кала) адавереские известняки были картированы на всей территории материковой Эстонии уже за пределами предполагаемой зоны перехода к велизеским мергелям.

Детальное исследование нами кернов буровых скважин, пройденных вдоль побережья материковой части Әстонии (скважины Кийдева, Виртсу, Варбла, Селисте, Икла; см. рис. 1 и 2), а также на о. Сааремаа (Охесааре, Кингисепп, Мустъяла, Карья-Пярсамаа; см. рис. 3 и 5), подтверждает, что пентамеровые слои адавереского горизонта действительно распространяются почти на всей территории юго-запада Эстонии и имеют достаточно четкую, очевидно синхронную, верхнюю границу.

Ниже приводится аргументация этих выводов. Авторы выражают искреннюю признательность Л. Сарву, В. Журавлевой, Р. Мяннилю и М. Рубелю за использованные в статье палеонтологические определения.

\section{Литологические критерии корреляции}

Изученные разрезы образуют вдоль западного побережья материковой Эстонии профиль длиной свыше $130 \kappa м$, пересекающий фациальные зоны ордовикско-силурийского Балтийского бассейна в направлении их 


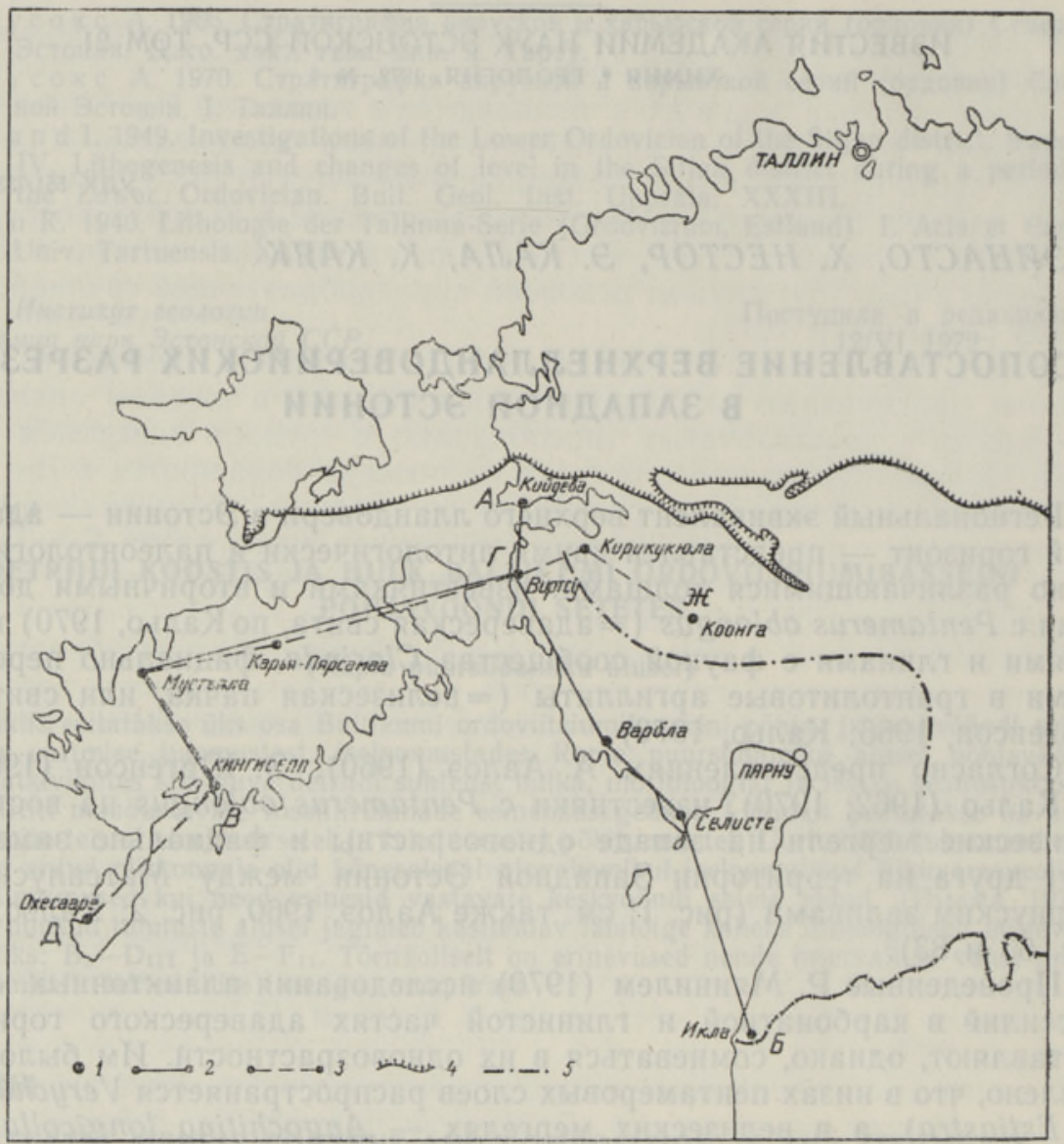

Рис. 1. Схема расположения изученных буровых скважин.

1 - буровые скважины; 2 - профили сопоставления разрезов; 3 - линия корреляции верхнелландоверийских отложений; 4 - северная граница распространения верхнелландоверийских отложений, уточненная в ходе геологической съемки Э. Кала; 5 - граница карбонатной и глинистой литофаций адавереского горизонта по А. Аалоэ (1960).

наибольшей изменчивости. Нижележащие средне- и нижнелландоверийские (а также ордовикские) отложения на обоих концах этого профиля в фациальном отношении существенно различаются, так как относятся к двум разным структурно-фациальным регионам (Мянниль, 1966; Кальо и др., 1970). Трансгрессивно залегающие верхнелландоверийские известняки, наоборот, отличаются выдержанностью мощности и литологических признаков. Во всех изученных разрезах на разных чистых известняках райккюлаского горизонта (рис. 2,б) с четко выраженным перерывом залегает относительно однородный комплекс изменчиво-глинистых комковатых тонкокристаллических илисто-детритовых известняков, содержащий типичную бентосную раковинную фауну: строматопороидей, кораллов, моллюсков, остракод и брахиопод. Из последних на разных уровнях обнаружен Pentamerus oblongus, образующий местами скопления и маломощные банки. Мощность этого комплекса, составляющего пентамеровые слои адавереского горизонта, также мало изменяется по данному профилю (от $21 \mu$ в скв. Кийдева до $17 \mu$ в скв. Селисте). 
Во внешне однородных комковатых известняках с Pentamerus oblongus установлена седиментационная ритмичность, заключающаяся в повторном направленном изменении в разрезе глинистости и текстурной картины пород, а также состава органических остатков. Низы ритмов $(0,05-0,6$ м) представлены зеленовато-серым глинистым мергелем с единичными комками микрокристаллического глинистого известняка. Детрит встречается редко. Преобладающая по мощности средняя часть ритмов сложена серым илисто-детритовым тонко- или микрокристаллическим комковатым (внизу) и полукомковатым (вверху) известняком с волнистыми прослойками детритового известкового мергеля. В этой части ритма встречаются частые строматопороидеи (нередко пиритизированные, захороненные в опрокинутом положении). Верхи ритмов $(0,25-0,4$ м) сложены желтовато-серым микро-или скрытокристаллическим известняком с редким содержанием детрита и волнистыми прослойками коричневато-серого битуминозного мергеля мощностью 0,5-2 см. В известняке обильно встречаются очень характерные четко выраженные ходы илоедов, заполненные зеленоватым, более мягким глинистым мергелем. Массовое скопление створок Pentamerus oblongus чаще всего приурочено к переходу от средней части ритма к верхней. Мощность ритмов колеблется от 0,5 до $3,2 \mu$, обычно же составляет $1,5-2,0 \mathrm{M}$. Внутри ритмов изменения плавные. Границы ритмов резкие, часто представлены поверхностью перерыва. Общее количество ритмов в пентамеровых слоях достигает двенадцати (рис. 2).

Иногда ритмы выражены не столь четко - может отсутствовать нижний мергель, нередко также скрытокристаллический известняк в кровле ритма. Наиболее выдержанным и по внешнему облику керна легко обнаруживаемым признаком служат характерные ходы илоедов в верхах ритмов.

Ритмичное чередование известняков и мергелей в пентамеровых слоях может стать поводом для утверждения о латеральном замещении пентамеровых слоев и велизеских мергелей. В частности, так, очевидно, интерпретировался разрез скв. Эйдапере (см. Кальо, 1970, рис. 63), в котором некоторые аномально мощные нижние части ритмов рассмотрены как «языки» велизеской свиты. Выдержанность ритмов на большой территории опровергает такое истолкование.

Ритмичность в общих чертах выдерживается в пределах почти всего изученного нами профиля, позволяя внутри пентамеровых слоев прослеживать целый ряд коррелятивных уровней (границы ритмов) и тем самым сопоставлять недалеко друг от друга расположенные разрезы (рис. 2).

Наиболее надежным маркирующим уровнем в пентамеровых слоях служит единичный мощный $(5-20 \mathrm{~cm})$ прослой твердого двуслойного (желтоватого в нижней и синеватого в верхней частях) алевритистого слюдистого метабентонит а, залегающего непосредственно выше границы между восьмым и девятым ритмами (см. рис. $2,4,5$, слой «О»). Этот прослой так наз. опорного метабентонита вскрыт в Западной Эстонии многими скважинами.

На рассматриваемом профиле (рис. 2) только в скв. Икла опорный метабентонит не был обнаружен. Сходные с пентамеровыми слоями комковатые илисто-детритовые, в разной степени глинистые известняки залегают здесь в интервале $304,5-322,3$ м над мощной толщей однородных желтовато-серых скрыто-и микрокристаллических известняков райккюлаского горизонта, покрываясь частично красноцветными глинистыми мергелями. Такое залегание, а также сходный литологический облик и выдержанная мощность этих известняков позволяют сопоставить данную 
часть разреза с пентамеровыми слоями адавереского горизонта, хотя не столь четко выраженная ритмичность и большая глинистость породы не дают возможности для проведения уверенной литологической корреляции внутри рассматриваемых слоев. Әта часть разреза включает слои, отнесенные раньше (Кальо, Вингисаар, 1969) к кулламааской пачке райккюлаского горизонта $(311,5-322,3$ м), поэтому для обоснования ее корреляции с пентамеровыми слоями ниже будут привлечены дополнительно некоторые палеонтологические критерии.

a) Икла

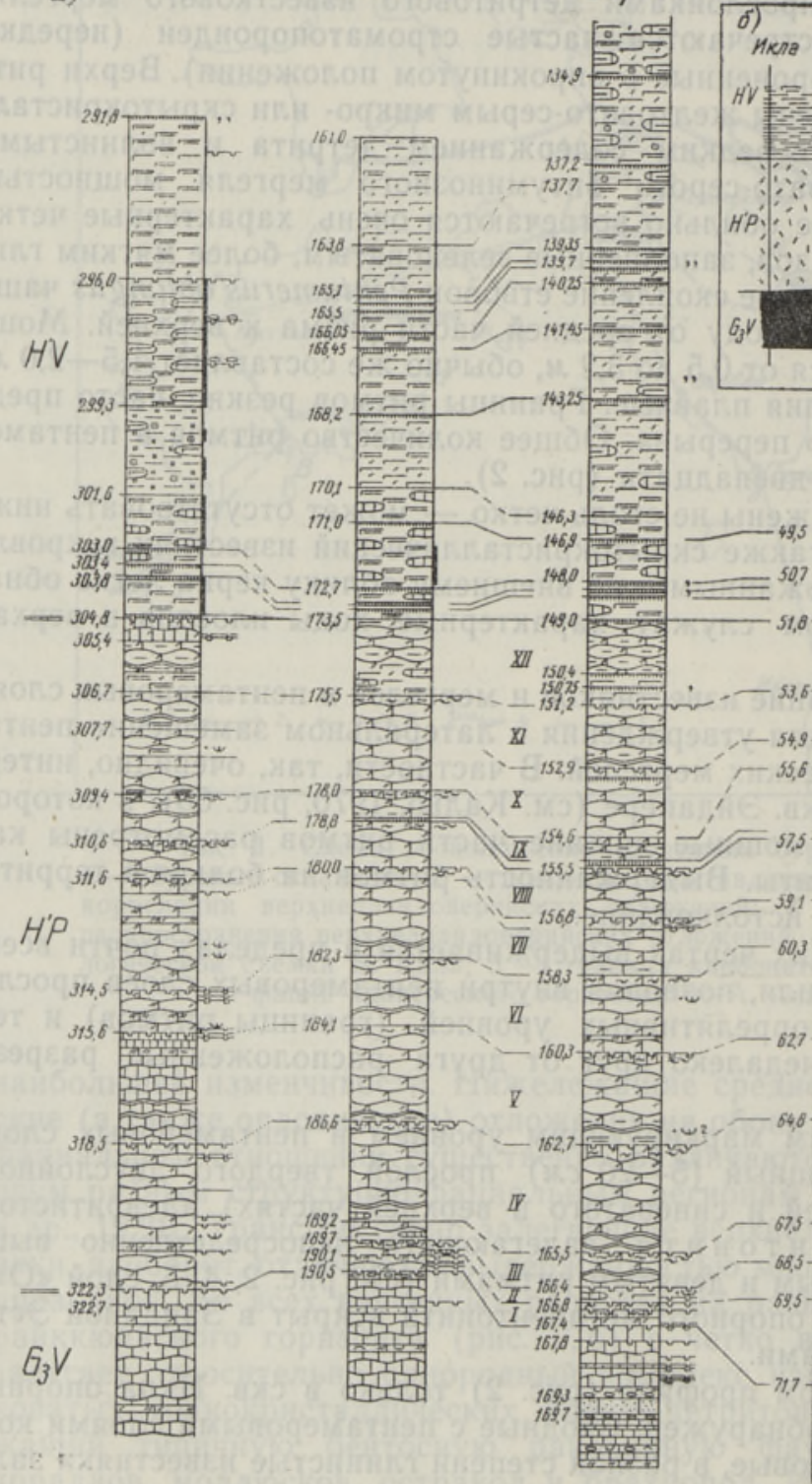

Ceлucme

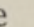


Слои с Pentamerus oblongus распространяются также на о. Сааремаa, сохраняя и там в общих чертах свой литологический облик и палеонтологическую характеристику. Только общая глинистость пород там заметно увеличивается главным образом за счет увеличения мощности нижних частей седиментационных ритмов, представленных глинистыми мергелями или глинами.

Пересмотр кернов скважин Қингисепп и Мустъяла (рис. 3) показал, что ниже красноцветных глинистых мергелей и глин, отнесенных к велизеским слоям, в этих разрезах имеется такой же комплекс глинистых илисто-детритовых комковатых известняков с Pentamerus oblongus, являющийся непосредственным продолжением к западу пентамеровых слоев. Обоими скважинами вскрыт также прослой опорного метабентонита. В Мустъяла он залегает в интервале $124,51-124,70$ м, в Кингисеппе - 215,40-215,45 м. В скв. Кингисепп, в нижней половине той части разреза, которая отнесена нами к пентамеровым слоям $(220,7-225,1$ м $)$, встречается много поверхностей перерыва. Характерную для пентамеровых слоев на западе материковой Эстонии ритмичность не удалось проследить из-за плохого состояния керна. В скв. Мустъяла ритмичность выражена очень четко, однако нижняя, мергелевая часть ритмов, является гораздо более мощной, преобладая иногда над остальной, известняковой, частью. Ритмичность и опорный прослой метабентонита позволяют с достаточной уверенностью сопоставить разрез Мустъяла с профилем на материковой Эстонии (рис. 3). При этом следует отметить, что скв. Мустъяла не вскрывает нижнюю границу адавереского горизонта.

Единственным в Западной Эстонии разрезом, где непосредственно выше палеонтологически доказанных райккюласких известняков без внешне заметных признаков перерыва залегают глинистые мергели, глины и аргиллиты с верхнелландоверийскими граптолитами (Кальо, 1962) - это разрез скв. Охесааре. На этой основе главным образом и укоренилось представление о фациальном замещении пентамеровых известняков в западном направлении полностью мергелями велизеской свиты.

Такому представлению, однако, противоречит отсутствие в нижней части комплекса мергелей и глин адавереского горизонта прослоя опорного метабентонита. Поэтому мы поддерживаем мнение Р. Мянниля

Рис. 2. Сопоставление пентамеровых слоев по линии А-Б (Кийдева-Икла) (а) и их фациальная интерпретация (б).

Римскими цифрами обозначены седиментационные ритмы.

1 - известняки скрыто- и микрокристаллические; 2 - известняки илисто-мелкодетритовые; 3 - известняки несортированно илисто-детритовые; 4 - известняки мелкодетритовые; 5 - известняки крупнодетритовые; 6 - известняки глинистые; 7 - известняки вторично доломитизированные; 8 - мергели известковые (вверху) и глинистые (внизу); 9 - домериты доломитовые (вверху) и глинистые (внизу); 10 - глины карбонатные; 11 - более карбонатные комки в мергелях; 12 - комковатые текстуры, соотношение известняка и мергеля $1: 1 ; 13$ - средне- (вверху) и мелкокомковатые (внизу) текстуры, соотношение известняка и мергеля соответственно от $2: 1$ до $3: 1 ; 14$ - полукомковатые текстуры, соотношение известняка и мергеля $5: 1 ; 15$ - волнистослоистые текстуры; 16 - красноцветность отложений (вправо от основной колонки); 17 - прослои метабентонита; 18 - поверхности перерыва; 19 - грубообломочный материал (гальки); 20 - сгустковый и мелкообломочный материал; 21 - строматопороидеи; 22 - табуляты; 23 - находки Pentamerus oblongus; 24 - примесь глауконита; 25 надежная корреляция; 26 - вероятная корреляция; 27 - условная корреляция; $28-$ глинисто-карбонатные отложения удаленно-тиховодной (переходной) фации; 29 - илистодетритовые карбонатные отложения умеренно-мелководной (детритовой) фации; 30 илистые карбонатные отложения умеренно-мелководной фации; 31 - зернистые карбонатные отложения отмельной фации; 32 - биогермные образования в отмельной фации, 33 - линия размыва (выходы) отложений. 


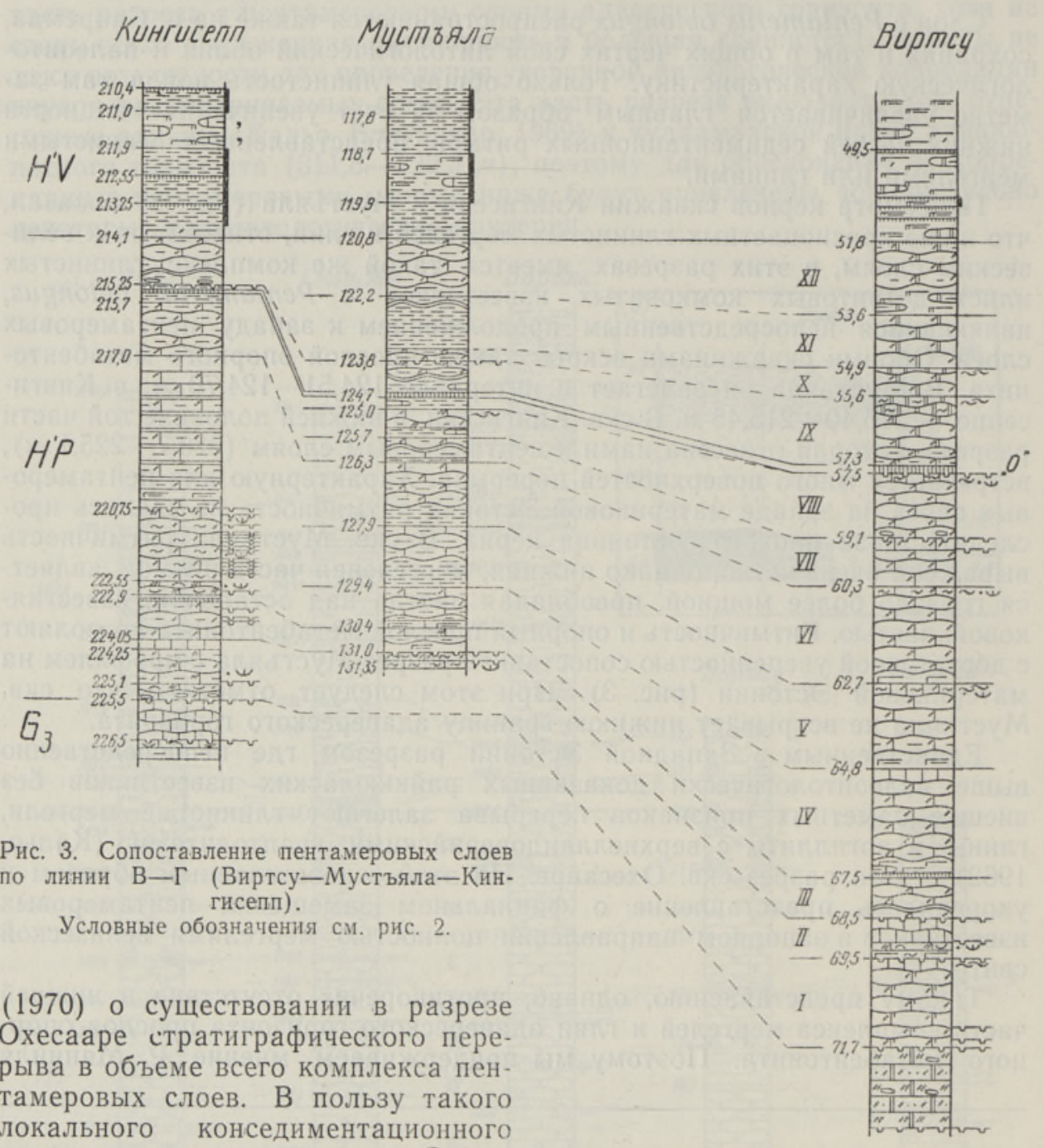
перерыва на юго-востоке о. Саaремаа говорит также отмеченная выше сокращенная мощность и очень большое количество поверхностей перерыва в пентамеровых слоях в разрезе соседней скв. Кингисепп.

Некоторые литологические признаки позволяют довольно уверенно коррелировать также низы велизеских мергелей. В Западной Эстонии в елизески е слои сложены мергелями и глинами, включающими редкие маломощные прослои и комки тонко- до микрокристаллического глинистого известняка и частые тонкие прослойки метабентонита.

В материковой части Әстонии велизеские мергели относительно карбонатные и содержат в изменчивом количестве несортированный детрит. Лишь самые низы свиты $(3-5$ м) лишены детрита. В этом интервале мергели глинистые с редкими комками микрокристаллического известняка. На юго-западе Эстонии (скважины Икла, Кингисепп, Мустъяла, Карья-Пярсамаа) в основании велизеских слоев залегают красноватокоричневые карбонатные глины. Маломощный «язык» красноцветных пород протягивается далеко на северо-восток и прослеживается еще в скважинах Селисте $(171,6-172,6$ м) и Виртсу $(50,7-50,9$ м). В велизе- 
ских слоях появляются многочисленные прослои метабентонитов, которые в лучше изученных кернах (скважины Виртсу, Варбла, Селисте) удалось точно коррелировать благодаря их различному составу и характеру (рис. 2). Корреляция по метабентонитам подтвердила, что красноцветность во всех разрезах появляется более или менее одновременно. Әто, в свою очередь, служит доказательством синхронности границы между пентамеровыми и велизескими слоями.

\section{Палеонтологические критерии корреляции}

Макрофауна пентамеровых слоев имеет односторонний характер и изменяется по площади также мало, как и литология отложений; она относится к сообществу Pentamerus. Кроме Pentamerus oblongus, в этих слоях обильны строматопороидеи и кораллы. Лишь в районе скв. Икла, где породы более глинистые, встречается * сообщество Stricklandia.

Для сопоставления пентамеровых слоев в данный момент наибольшую ценность имеют виды: Pentamerus oblongus и Estiastra magna (=Verychachium oligospinosum, Мянниль, 1970).

Конкретные находки Pentamerus oblongus из отдельных разрезов, обозначенные на профилях рис. 2 и 3, показывают, что этот вид распространяется практически на всей рассматриваемой нами территории Западной Эстонии. Чаще всего P. oblongus встречается в части разреза ниже опорного метабентонита. Выше его (4-5 м) P. oblongus обнаружен в разрезах скважин Коонга ** и Кирбла. Приведем теперь необходимые палеонтологические доказательства корреляции тех разрезов, для которых литологические критерии корреляции - наличие опорного метабентонита и ритмичное строение свиты - не так четки.

В разрезе скв. Кингисепп Pentamerus oblongus встречен в интервале $220,75-225,1$ м, т. е. в нижней половине известняков, принятых нами за пентамеровые слои.

В разрезе Мустъяла, где нижняя граница адавереского горизонта проводилась раньше по прослою опорного метабентонита (гл. 124,7 $\boldsymbol{M}$ по Аалоэ, 1960 и Юргенсон, 1966) или даже еше выше, Pentamerus oblongus встречен нами в самом забое скважины $(131,2-131,3$ м). В той же части разреза X. Нестором определены типичные адавереские виды страматопороидей Clathrodictyon variolare (Rosen) $(125,1 ; 125,3 ; 130,5$ м) и Ecclimadictyon fastigiatum (Nicholson) (130,8 м), что подтверждает литологическую корреляцию по опорному метабентониту и седиментационным ритмам.

В скв. Икла, где граница адавереского и райккюлаского горизонтов условно проводилась на глубине 311,5 м (Кальо, Вингисаар, 1969; Кальо, 1970), теперь обнаружены в интервале 308,1-321,0 м Pentamerus oblongus (определения M. Рубеля) и в интервале 307,8-318,2 м Estiastra magna (определения Р. Мянниля). Следовательно, весь интервал (311,5-322,3 м), ранее принятый за кулламааскую пачку райккюлаского горизонта, принадлежит пентамеровым слоям.

Хорошим критерием сопоставления отложений разреза Икла с северными разрезами оказываются данные распространения остракод (рис. 4). До самого последнего времени из пентамеровых известняков был известен лишь вид Hermannina hisingeri abbreviata (Schmidt) (см. Кальо, 1970 , с. 239$)$.

* Частное сообщение М. Рубеля.

Частное сообщение Э. Юргенсон. 
Новые определения показывают, что в нижней части пентамеровых слоев (в скв. Варбла начиная от опорного метабентонита; в Икла ниже гл. 310,6 м) преобладают следующие виды, до сих пор считавшиеся

\section{CXB ВАРБЛA}

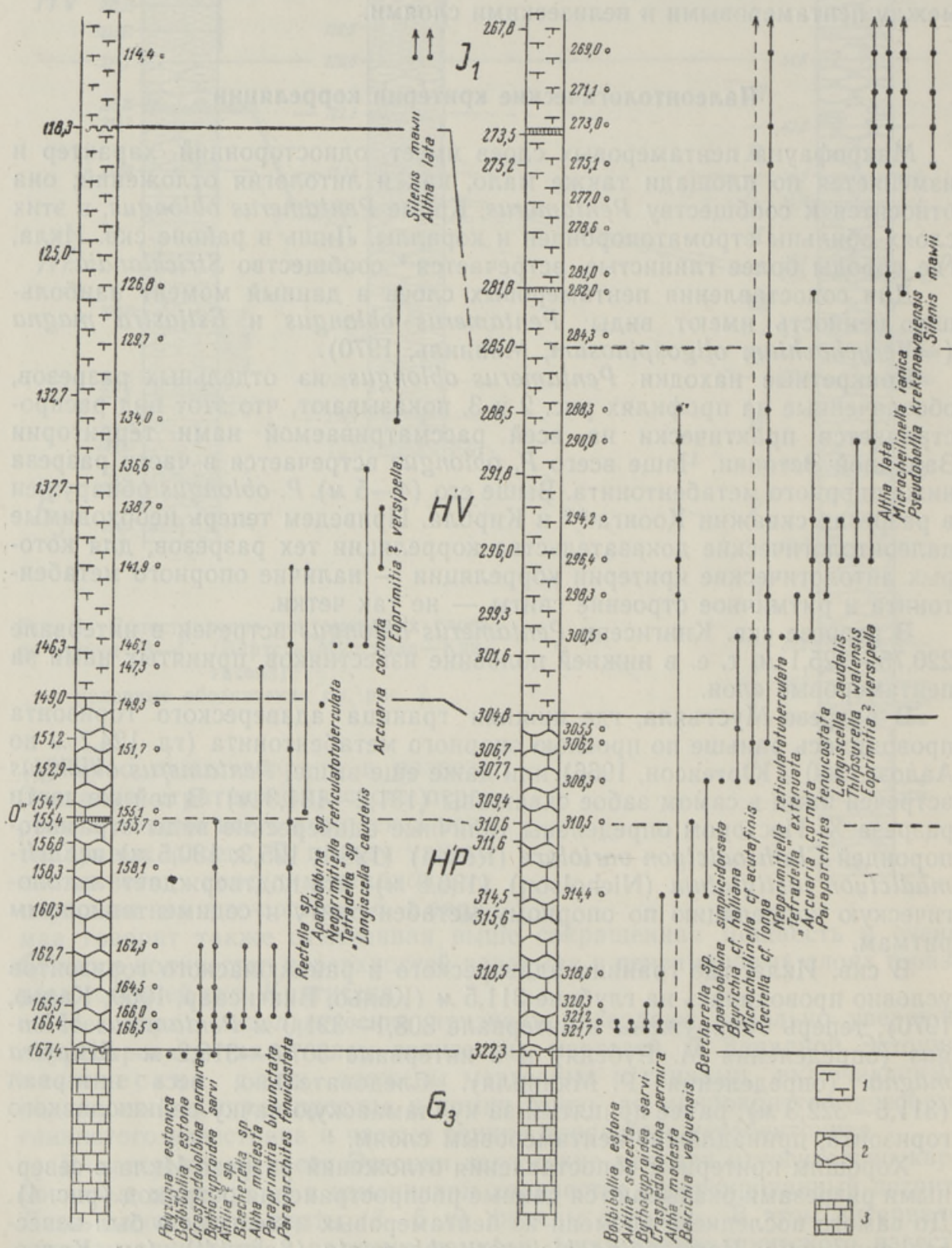

\section{СK6. ИKЛА}


характерными лишь для лежащих ниже райккюлаского и юуруского горизонтов: Bolbibollia estona Sarv, Aitilia senecta Sarv, Bythocyproidea sarvi Neckaja, Craspedobolbina permira Sarv, Paraprimitia bipunctata (Henningsmoen). (Последний вид известен из среднего лландовери Средней Прибалтики.) В низах пентамеровых слоев впервые появляются лишь единичные виды остракод (напр., в скв. Икла Silensis cf. subtriangulatus Neckaja, Beyrichia valguensis Sarv). Более заметное обновление остракодовой фауны начинается в верхах пентамеровых слоев, выше уровня опорного метабентонита. В этой части разреза появляются Beyrichia cf. halliana Martinsson, Rectella cf. longa, Apatobolbina simplicidorsata Martinsson. Только в нижней части велизеских слоев в обоих разрезах появляются Neoprimitiella reticulatotuberculata Neckaja, «Tetradella» extenuata Sarv, Arcuaria cornuta Neckaja, Longiscella caudalis (Jones), Eoprimitia? versipella Neckaja, в Икла еще и Thlipsurella walensis, - т. е. виды, которые до сих пор считались руководящими для адавереского горизонта Әстонии в целом (Сарв, 1970).

Верхняя граница адавереского горизонта в названных скважинах знаменуется появлением видов Altha lata Neckaja, Silenis mawii, Pseudobollia krekenavaiensis Neckaja, Microcheilinella ianica (Neckaja).

Исключительно хорошее совпадение распространения остракод в скважинах Варбла и Икла подтверждает корреляцию, сделанную по другим признакам. Кроме того, бросается в глаза существенная разница остракодовых фаун пентамеровых слоев и велизеских мергелей. Так как эти фауны залегают друг над другом, их различие логично объяснить прежде всего разновозрастностью, хотя определенное влияние экологических факторов здесь не исключено.

\section{Заключение}

Установление в Эстонии почти повсеместно пентамеровых слоев и синхронность их границы с вышележащими велизескими мергелями позволяют переоценить прежние корреляции западных - сааремааских разрезов - с более восточными (Коонга, Эйдапере и др.) (рис. 5). В последних доломитизированные мергели, залегающие выше известняков с Pentamerus oblongus, были раньше относимы к яанискому горизонту. В западных и юго-западных разрезах (напр., Икла, Мустъяла), наоборот, карбонатные породы под велизескими и яанискими мергелями включались уже в райккюлаский горизонт, т. е. граница между известняками и мергелями, которая на западе считалась нижней границей адавереского горизонта, к востоку становилась, постепенно понижаясь, его верхней границей (скв. Коонга). Однако, как видно на рис. 5, прослой опорного метабентонита может считаться контрольным репером, свидетельствующим о синхронности этой границы.

Возникновение неверной корреляции верхнелландоверийских разрезов становится понятным, если иметь в виду, что она появилась от сопоставления вторично доломитизированных восточных разрезов (напр., скв. Коонга) непосредственно с разрезами Мустъяла и Карья-Пярсамаа, ь которых адавереский горизонт был пройден не полностью, и с разрезом Oхесааре, в котором существует значительный стратиграфический перерыв.

Фациальная интерпретация отложений адавереского горизонта показывает, что пентамеровые известняки трансгрессивно покрывают разнофациальные карбонатные отложения нижне- и среднелландоверийского райккюлаского горизонта (рис. 2, б), отмечая в Северной Прибалтике 
начало известной позднелландоверийской трансгрессии. Начало отложения велизеских мергелей и глин отмечает, очевидно, вторую стадию достижение максимума трансгрессии. Эти же две стадии позднелландоверийской трансгрессии прослеживаются и в некоторых других регионах в Северной Европе (Нестор, 1972).

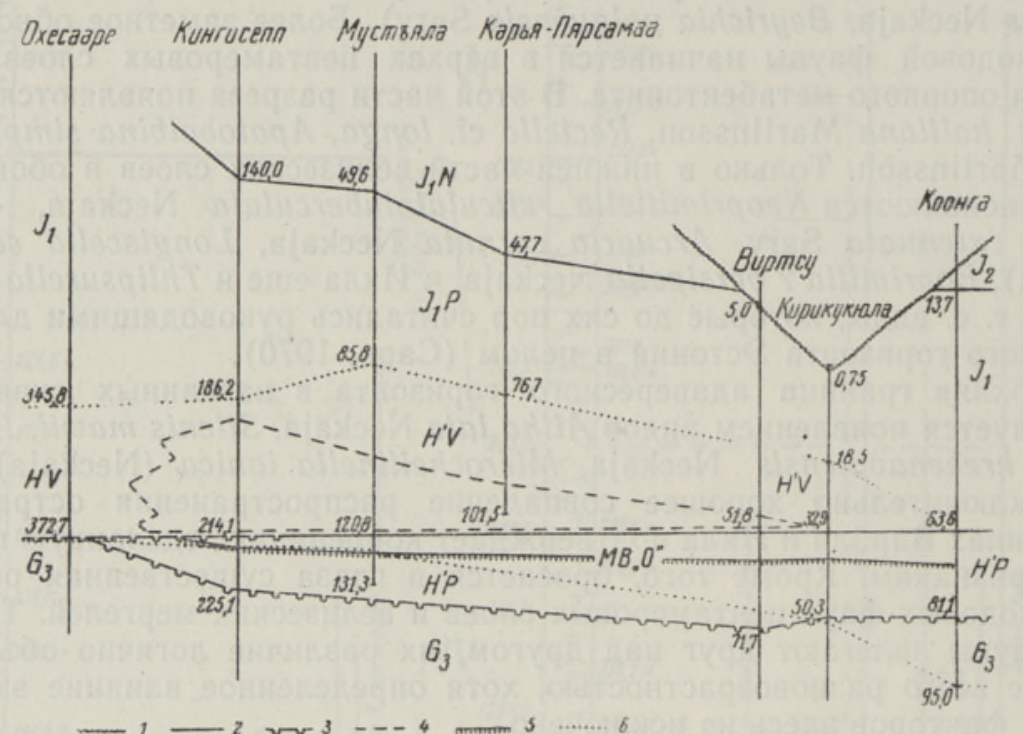

Рис. 5. Корреляционная схема верхнелландоверийских отложений по линии Д-Ж (Охесааре-Коонга) в интерпретации разных авторов. 1 - линия среза послесилурийской денудации; 2 - стратиграфические границы без признаков перерыва; 3 - стратиграфические границы, связанные с перерывом; 4 - контур красноцветных отложений; 5 - опорный метабентонит; 6 - границы адавереского горизонта по А. Аалоэ (1960), Д. Кальо (1970), Э. Юргенсон (1966).

Поэтому нам кажется, что причины позднелландоверийской трансгрессии следует видеть не столько в местных тектонических движениях, а, вероятно, в более общих эвстатических явлениях, обусловливавших в отдаленных друг от друга районах аналогичные изменения в осадконакоплении. Такая интерпретация означает, что позднелландоверийская трансгрессия началась и достигла максимума одновременно в различных регионах. Следовательно, граница между слоями с Pentamerus oblongus и велизескими мергелями приобретает межрегиональное корреляционное значение. Поэтому эти подразделения целесообразно рассматривать в качестве не литостратиграфических, а самостоятельных региональных хроностратиграфических подразделений.

\section{Л И Т Е Р А Т У Р А}

А а лоэ А. 1960 . Новое в стратиграфии силура Эстонии. Тр. Ин-та геол, АН ЭССР, V. А алоэ А. 1970. Яаниский горизонт. В кн.: Силур Эстонии. Таллин,

К а ль Д Д. 1962. О границе лландовери и венлока в Прибалтике. Тр. Ин-та геол. АН ЭССР, $\mathbf{x}$.

К аль о Д. 1970. Адавереский горизонт. В кн.: Силур Эстонии. Таллин.

Кальо Д., Винги са а р П. 1969. О разрезе райккюлаского горизонта на южной окраине Эстонии. Изв. АН ЭССР, Хим. Геол., 18, № 3.

Кальо Д., Клааманн Э., НесторХ., Эйнасто Р., Юргенсон Э. 1970. Фащии и развитие бассейна. В кн.: Силур Эстонии. Таллин. 
Мянниль Р. 1966. История развития Балтийского бассейна в ордовике. Таллин.

М яннил ь Р. 1970. Кислотоустойчивые микрофоссилии. В кн.: Силур Эстонии. Таллин.

Н естор Х. 1972. О возрастном диапазоне слоев с Pentamerus oblongus и о характере позднелландоверийской трансгрессии в Северной Европе. Изв. АН ЭССР, Хим. Геол., 21, № 4.

С а р в Л. 1970. Остракоды. В кн.: Силур Эстонии. Таллин.

Ю р ген сон Э. 1966. Литология лландоверийских отложений Эстонии. Таллин.

\author{
Ннститут геологии \\ Академии наук Эстонской ССР \\ Управление геологии \\ Совета Министров Эстонской ССР
}

Поступила в редакцию 5/IV 1972

\section{R. EINASTO, H. NESTOR, E. KALA, K. KAJAK}

\section{OLEMLÄNDOUVERI LÄBILOOIGETE RŐÖBISTAMINE LAANE-EESTIS}

Saaremaa ja Mandri-Eesti läänepoolsemate puursüdamike uurimisel selgus, et peaaegu kõigis läbilõigetes (välja arvatud Ohesaare Sôrve poolsaarel) lasub raikküla lademel ca $20 \mathrm{~m}$ paksune muguljate mudalis-detriitsete lubjakivide kompleks, milles erinevatel tasemetel esineb Pentamerus oblongus. Viimane asjaolu lubab arvata, et need lubjakivid kuuluvad adavere lademe pentaameruskihtidesse, mille levik senini arvati piirduvat pōhiliselt Matsalu-Pärnu lahe joonelt ida poole jääva alaga. Lääne-Eestis pentaameruskihtide külgmiseks fatsiaalseks analoogiks peetud velise merglid lasuvad kôigis läbilőigetes pentaamerustega lubjakivide peal.

Väliselt ühtlased pentaameruskihid koosnevad Lääne-Eestis kuni 12-st suurel alal jälgitavast setterütmist. Koos pentaameruskihtide ülaosas ja velise merglites esinevate metabentoniidi kihtidega annavad nad tunnistust pentaameruskihtide ülemise piiri suhtelisest sünkroonsusest. Pentaameruskihtide puudumine Ohesaare läbilöikes seletub ilmselt kohaliku stratigraafilise lüngaga.

Lääne-Eesti ülemländouveri läbilōikel on suur sarnasus Inglismaa ja Skandinaavia vastava ajajärgu teatud läbilőigetega, milles esinevad kaks analoogilist litoloogiliselt ja paleontoloogiliselt erinevat osa. Need asjaolud kokku vihjavad sellele, et pentaameruslubjakive ja velise mergleid oleks otstarbekas vaadelda kahe iseseisva ajalis-stratigraafilise üksusena.

\section{R. EINASTO, H. NESTOR, E. KALA, K. KAJAK}

\section{CORRELATION OF THE UPPER LLANDOVERIAN SECTIONS IN WEST ESTONIA}

In the course of a study of the westernmost cores on Saaremaa Island and in the continental part of Estonia it was stated that in nearly all of the cores (except in the Ohesaare boring on the Sōrve Peninsula) the Raikküla Stage is overlain by an approximately 20-metre-thick complex of biomicritic calcarenites, at different levels of which Pentamerus oblongus occurs. The latter fact allows us to attribute those limestones to the Pentamerus Beds of the Adavere Stage, whose distribution was up to the present time considered to be mainly limited to the area situated in the east of the line running from the Matsalu Bay to Pärnu. The Velise Ma:ls, hitherto assumed to be a lateral facial analogue of Pentamerus Beds in West Estonia, actually lie in all the sections above the Pentamerus Limestones.

The Pentamerus Beds of West Estonia, of a rather uniform exterior appearance, actually consist of up to 12 sedimentological rhythms that are traceabie over a large area. Together with the metabentonite interlayers in the upper part of the Pentamerus Beds and in the Velise Marls, thev give evidence of the relatively synchronous character of the upper boundary of the Pentamerus Beds. The absence of Pentamerus Beds in the section of Ohesazre boring is obviously explainable by a local non-sequence:

The Upper Llandoverian sections of West Estonia reveal considerable analogy with certain sections of England and Scandinavia of the same age, in which similar two lithologically and palaeontologically different parts may be stated. Those phenomena point to the fact that the Pentamerus Limestones and Velise Marls ought to be regarded as two independent chronostratigraphical units. 